\title{
Frequency of Morphologic Prognostic Factors in Surgically Treated Colorectal Cancer
}

\author{
Inese Drike*, Ilze Strumfa*, Andrejs Vanags**, Janis Gardovskis** \\ *Department of Pathology, Riga Stradins University, Latvia \\ **Department of Surgery, Riga Stradins University, Latvia
}

\begin{abstract}
SUMMARY
Introduction. Colorectal cancer is one of the most frequent malignant tumours worldwide. In Latvia, the incidence and mortality from colorectal cancer has increased over the past five years. Surgery is the mainstay of colorectal cancer treatment. However, the prognosis of an individual patient after the operation depends on many factors. Here, we report the prognostically important morphologic factors in potentially radically operated colorectal cancer patients in order to create the "morphologic prognostic portrait" - the basic morphologic characteristics of colorectal cancer in Latvian patients. Such data could be helpful in prognostic estimates.
\end{abstract}

Aim of the study was to describe the local tumour spread by $\mathrm{pT}$, to evaluate the occurrence of certain morphologic prognostic factors and to assess lymph node involvement in potentially radically operated colorectal cancer patients.

Material and methods. In a retrospective study, 173 consecutive patients who underwent a potentially radical operation in a single university hospital within the year 2012 were identified by archive search. The pathology reports that have been created by protocol approach and diagnostic microscopy slides were reanalysed. Tumour morphology and pTN parameters were assessed according to the World Health Organization and the American Joint Committee on Cancer classifications.

Results. The study included 98 women $(56.6 \%)$ and 75 men $(43.4 \%)$. The mean age of patients was 68.5 years [95\% confidence interval: $66.9-70.1]$. Only $4.6 \%$ [2.4 - 8.9] of patients were younger than 50 years. The most frequent histological tumour types were colorectal adenocarcinoma in $86.7 \%$ [80.8 - 90.9] patients and mucinous carcinoma in $9.2 \%$ [5.7 - 14.5] of patients. Evaluating the pT parameter, pT3 was found in 43.2\% [36.1 - 50.6] and pT4 in 39.8\% [32.8 - 47.2] of cases. Lymphatic invasion was found in $35.1 \%$ [25.3 - 46.2] of pT3 and 75.4\% [64.0 - 84.0] of pT4 cases; $p<0.001$. Perineural cancer invasion in $p$ T3 and pT4 tumours was found in 29.9\% [20.8 - 40.9] and 69.6\% [57.9-79.2], respectively; $p<0.001$.

Conclusions. Colorectal cancer affects both genders with equal frequency. The tumour is mostly diagnosed after the age of 60 years. Adenocarcinoma is the predominant colorectal cancer type in radically operated patients. Perineural and lymphatic invasion in pT4 tumours is statistically significantly more frequent than in less advanced tumours and thus may be pathogenetically linked to wide local tumour spread.

Key words: colorectal cancer, morphology, prognostic factors, synchronous colorectal cancer

\section{INTRODUCTION}

Colorectal cancer is one of the most frequent malignant tumours worldwide. In Latvia the incidence and mortality from colorectal cancer has increased (Figure 1) over the past five years. According to the Centre for Disease Prevention and Control of Latvia, there were 1233 new colorectal cancer cases in Latvia in 2012. Among these cases, the largest proportion of patients was diagnosed in the third and fourth stage, characterised by cancer spread beyond the primary tumour (data by the Centre for Disease Prevention and Control of Latvia). For colorectal cancer, the known unfavorable prognostic factors comprise marked local spread of the tumour, metastatic involvement of the lymph nodes, the development of perforation, presence of residual adenoma, and invasion in the perineural space and blood or lymphatic vessels [Marzouk and Schofield, 2011; Walsh and Carey, 2013]. Presence of synchronous second colorectal carcinoma has been analysed as a prognostic factor as well [Cunliffe et al., 1984; Takeuchi et al., 1997].

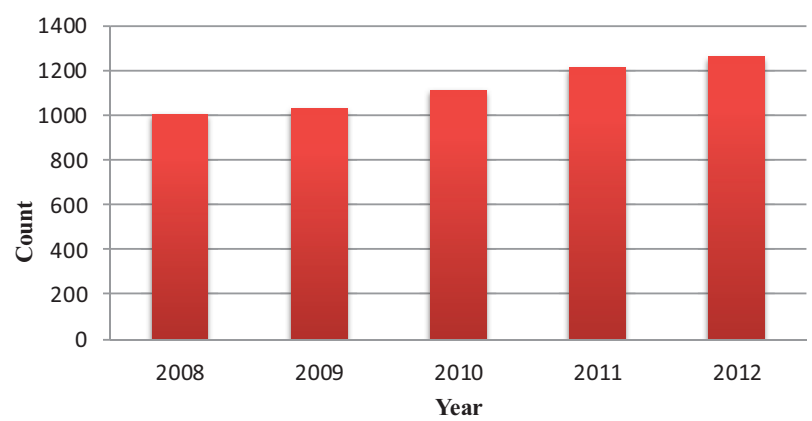

New colorectal carcinoma cases, 2008 - 2012

Fig. 1. The number of newly diagnosed colorectal carcinoma cases in Latvia per year.

Data: the Centre for Disease Prevention and Control of Latvia 


\section{AIM OF THE STUDY}

The aim of this study was to describe the local tumour spread by $\mathrm{pT}$, the frequency of certain morphologic prognostic factors and to assess lymph node involvement in radically operated colorectal cancer patients from Latvia.

\section{MATERIAL AND METHODS}

In a retrospective study, 173 consecutive patients who underwent potentially radical surgical treatment of colorectal cancer in a single university hospital within 2012 (January $1^{\text {st }}-$ December $31^{\text {st }}, 2012$ ) were identified by archive search. The corresponding pathology reports and diagnostic microscopy slides were retrieved. Within the present study, potentially radical operations were defined as major colonic and rectal resections, namely, partial, subtotal or total colectomy, anterior rectal resection, Hartmann operation, rectosigmoidectomy and rectal extirpation [Bhangu et al., 2013]. The data on neoadjuvant chemotherapy were assessed by medical records. The tumour morphology and pTN parameters were evaluated according to the classifications and criteria as defined by World Health Organization and the American Joint Committee on Cancer [Hamilton and Aaltonen, 2010; Edge et al., 2010]. The presence of perforation and synchronous second colorectal carcinoma was analysed by pathology reports. Tumour perforation was defined as a defect in the bowel wall through the tumour [Swamy, 2010]. The presence of residual adenoma, perineural and intraneural invasion and involvement of lymphatic vessels and veins in the process were analysed in the retrieved diagnostic pathology slides [Fleming et al., 2012]. As the current recomendations highlight the importance of a sufficient number of lymph nodes found for adequate staging of colorectal cancer [Compton et al., 2000; Kuijpers et al., 2013], the total number of retrieved lymph nodes was also assessed. The slides were routinely stained with hematoxylin and eosin. Additional immunohistochemical investigation was performed upon necessity if the tumour histogenesis was otherwise unclear. Descriptive statistical analysis was perfomed. The descriptive data were expressed as mean \pm standard deviation (SD), median with interquartile range or frequency. To detect statistically significant differences, the $95 \%$ confidence interval (CI) was calculated by CIA software (Altman et al., 2000) and the findings were further confirmed by the $\chi^{2}$ test regarding frequency and two sample t-test regarding the mean values. Differences were considered statistically significant, if $p$ value was less than 0.05 .

\section{RESULTS}

The study included 173 patients: 98 women (56.6\%) and 75 men $(43.4 \%)$. The mean age of patients was $68.5 \pm$ SD 10.6 years [95\% CI: $66.9-70.1$ ], ranging from 41 to 97 years. Only 8 patients were younger than 50 years, comprising $4.6 \%$ [2.4 - 8.9] of the study group (Figure $2)$. No statistically significant difference was found regarding the mean age of women estimated as $69.7 \pm$
SD 10.4 years [67.7 - 71.8] and men estimated as $67.0 \pm$ SD 10.6 [64.5 - 69.4]. The lack of statistical difference was confirmed by $\mathrm{p}=0.811$.

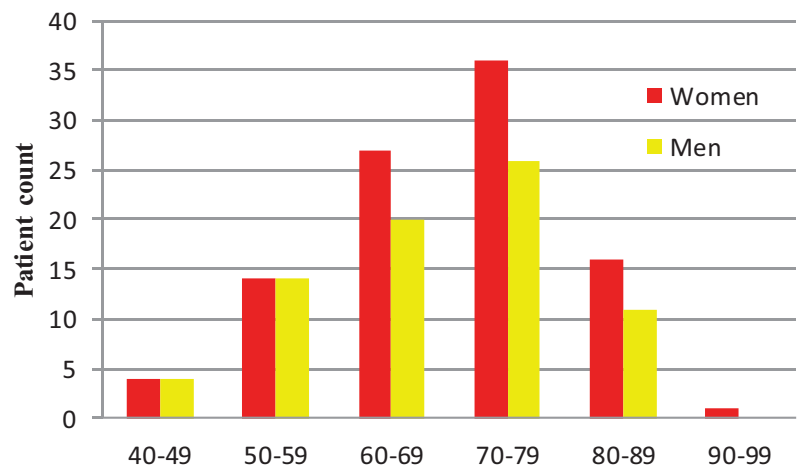

Patient age groups in colorectal cancer

Fig. 2. The age and gender distribution of the studied surgically treated colorectal carcinoma cases

Colorectal adenocarcinoma was found in 86.7\% [80.8 90.9] of patients with colon cancer. Mucinous carcinoma was found in $9.2 \%$ [5.7 - 14.5] cases. There were single cases of medullary and undifferentiated carcinoma as well as few cases of primary signet ring cell carcinoma of the large bowel and moderately differentiated (G2) neuroendocrine tumour (Table 1, Figure 3).

Table 1. Histological type of colorectal tumour by gender

\begin{tabular}{|l|c|c|c|c|}
\hline Tumour type & Number & $\begin{array}{c}\text { Frequency, } \\
\%[95 \% \text { CI] }\end{array}$ & Women & Men \\
\hline $\begin{array}{l}\text { Adeno- } \\
\text { carcinoma }\end{array}$ & 150 & $\begin{array}{c}86.7 \\
{[80.8-90.9]}\end{array}$ & 84 & 66 \\
\hline $\begin{array}{l}\text { Mucinous } \\
\text { carcinoma }\end{array}$ & 16 & $\begin{array}{c}9.2 \\
{[5.7-14.5]}\end{array}$ & 9 & 7 \\
\hline $\begin{array}{l}\text { Signet ring } \\
\text { cell carcinoma }\end{array}$ & 3 & $\begin{array}{c}1.7 \\
{[0.5-4.9]}\end{array}$ & 2 & 1 \\
\hline $\begin{array}{l}\text { Neuro- } \\
\text { endocrine } \\
\text { tumour }\end{array}$ & 2 & $\begin{array}{c}1.2 \\
{[0.3-4.1]}\end{array}$ & 2 & 0 \\
\hline $\begin{array}{l}\text { Medullary } \\
\text { carcinoma }\end{array}$ & 1 & $\begin{array}{c}0.6 \\
{[0.1-3.2]}\end{array}$ & 0 & 1 \\
\hline $\begin{array}{l}\text { Undifferen- } \\
\text { tiated } \\
\text { carcinoma }\end{array}$ & 1 & $\begin{array}{c}0.6 \\
0.1-3.2]\end{array}$ & 1 & 0 \\
\hline
\end{tabular}

Abbreviation in the Table: CI, confidence interval 

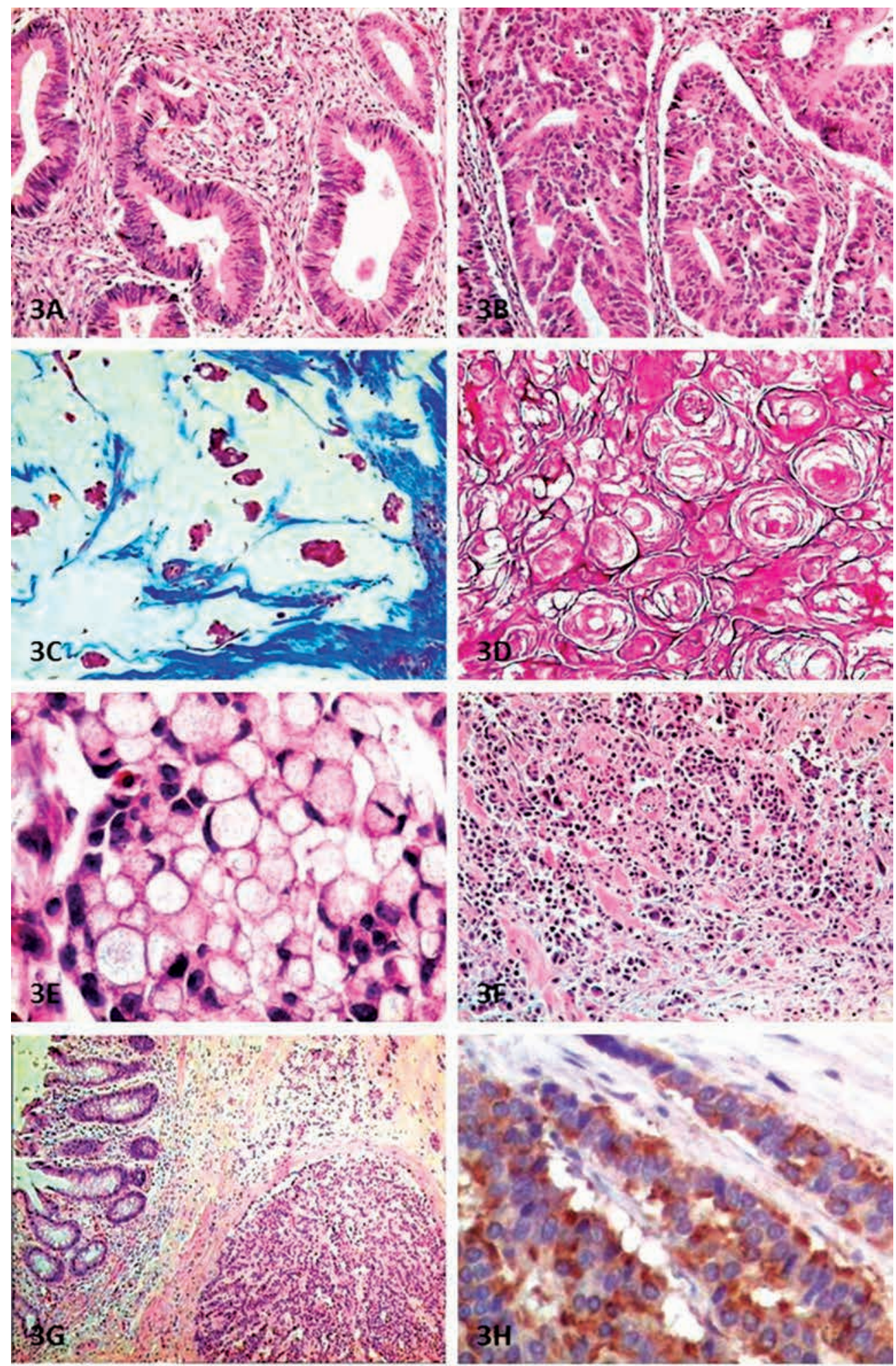

Fig. 3. The histological types of colorectal carcinoma. 3A-B, adenocarcinoma. Note low-grade architecture in $3 \mathrm{~A}$ and high-grade in 3B; $3 \mathrm{C}-\mathrm{D}$, mucinous carcinoma. Note mucus lakes in both $3 \mathrm{C}$ and $3 \mathrm{D}$ as well as slight fibrosis in 3C; 3E, signet ring cell carcinoma; 3F, undifferentiated carcinoma; 3G-H, neuroendocrine tumour. Note the characteristic architecture in $3 \mathrm{G}$ and cytoplasmic expression of synaptophysin in 3H. 3A, B, E, F, G: haematoxylin-eosin; 3C, Masson's trichrome; 3D, PAS; 3H, immunoperoxidase. Original magnification: 3A, B, C, D, F, G: 100x; 3E and H: 400x. 
Evaluating the anatomic localization of the tumour and the related type of the operations, it was found that radical surgery in relation to colorectal cancer was performed mostly on the left part of the bowel, representing $76.9 \%$ [70.1 - 82.5] of cases. The most frequent single localization of colorectal cancer was the rectum, where the tumour was detected in 39.3\% [32.346.7] of cases (Table 2). Few patients affected by rectal cancer underwent neoadjuvant treatment: $7.4 \%$ [2.8 16.5].

Table 2. The anatomic localisation of surgically treated colorectal carcinoma

\begin{tabular}{|l|c|c|c|}
\hline \multicolumn{1}{|c|}{ Site } & $\begin{array}{c}\text { Number } \\
\text { of cases }\end{array}$ & $\begin{array}{c}\text { Frequency, } \\
\%\end{array}$ & $\begin{array}{c}\text { 95\% CI of the } \\
\text { frequency }\end{array}$ \\
\hline Caecum & 11 & 6.3 & $3.6-11.0$ \\
\hline $\begin{array}{l}\text { Ascending } \\
\text { colon }\end{array}$ & 22 & 12.7 & $8.5-18.5$ \\
\hline $\begin{array}{l}\text { Transverse } \\
\text { colon }\end{array}$ & 20 & 11.6 & $7.6-17.2$ \\
\hline $\begin{array}{l}\text { Descending } \\
\text { colon }\end{array}$ & 7 & 4.1 & $1.9-8.1$ \\
\hline $\begin{array}{l}\text { Sigmoid } \\
\text { colon }\end{array}$ & 45 & 26.0 & $20.1-33.0$ \\
\hline Rectum & 68 & 39.3 & $32.3-46.7$ \\
\hline
\end{tabular}

Abbreviation in the Table: CI, confidence interval

Left-sided colorectal adenocarcinoma accounted for 117 cases or $87.9 \%$ [81.3 - 92.5] of left side operations. Mucinous colorectal carcinoma was found in $9.0 \%$ [5.2 - 15.1] of all left side operations. There were 62 cases of rectal adenocarcinoma, corresponding to $41.3 \%$ [33.8 - 49.3] of the total number of adenocarcinomas. In sigmoid colon, adenocarcinomas were found in $26.0 \%$ [19.6 - 33.6] of cases. Mucinous carcinoma of the sigmoid colon represented $37.5 \%$ [18.5-61.4] of all mucinous cancer cases (Table 3 ).

Table 3. Histological type of tumour by anatomic localisation site

\begin{tabular}{|l|c|c|c|c|c|c|}
\hline \multirow{2}{*}{$\begin{array}{l}\text { Localisa- } \\
\text { tion }\end{array}$} & $\begin{array}{c}\text { Adeno- } \\
\text { carci- } \\
\text { noma }\end{array}$ & $\begin{array}{c}\text { Muci- } \\
\text { nous } \\
\text { carci- } \\
\text { noma }\end{array}$ & $\begin{array}{c}\text { Signet } \\
\text { ring } \\
\text { cell } \\
\text { carci- } \\
\text { noma }\end{array}$ & $\begin{array}{c}\text { Medul- } \\
\text { lary } \\
\text { carci- } \\
\text { noma }\end{array}$ & $\begin{array}{c}\text { Neuro- } \\
\text { endo- } \\
\text { crine } \\
\text { tumour }\end{array}$ & $\begin{array}{c}\text { Undif- } \\
\text { feren- } \\
\text { tiated } \\
\text { carci- } \\
\text { noma }\end{array}$ \\
\hline Caecum & 8 & 2 & 0 & 0 & 1 & 0 \\
\hline $\begin{array}{l}\text { Ascen- } \\
\text { ding } \\
\text { colon }\end{array}$ & 19 & 2 & 0 & 0 & 0 & 1 \\
\hline $\begin{array}{l}\text { Trans- } \\
\text { verse } \\
\text { colon }\end{array}$ & 15 & 2 & 2 & 1 & 0 & 0 \\
\hline
\end{tabular}

Fig. 4. pT distribution in surgically treated colorectal carcinoma

The number of identified lymph nodes ranged from 1 to 33 . The median value was 11 , interquartile range 8. The mean number of investigated lymph nodes per patient was $11.8 \pm$ SD 6.4 [10.8 - 12.8]. In 80 cases $(46.2 \%)$, the number of identified lymph nodes reached or exceeded 12 while in $45(26.0 \%)$ cases the number of 
retrieved lymph nodes found was 8 to 11 . No metastasis in regional lymph nodes (pN0) was detected in $49.1 \%$ [41.8 - 56.5] of cases. The pNl spread ( $1-3$ metastases in regional lymph nodes) was identified in $27.8 \%$ [21.634.8] patients. If more than 12 lymph nodes were retrieved, $\mathrm{pNl}$ was detected in $28.7 \%$ [19.9 - 39.5] of cases and pN2 in $22.5 \%$ [14.7 - 32.8] of cases. In patients with 8 to 11 identified lymph nodes, $\mathrm{pNl}$ was found in $24.4 \%$ [ $14.2-38.7$ ] and pN2 in $20.0 \%$ [ $10.9-$ 33.8] of cases. Comparing the $\mathrm{pN}$ distribution ( $\mathrm{pNO}$ versus $\mathrm{pN} 1$ versus $\mathrm{pN} 2$ ) between the patients with less than 8 retrieved lymph nodes, $8-11$ or at least 12 identified lymph nodes, there were no statistically significant difference as shown by $\chi 2$ test, resulting in $p=0.917$. Perforation, defined as a complete defect in bowel wall through the tumour, was observed in 11 cases, corresponding to $6.4 \%[3.6-11.0]$ of the total number of cases. The pT4 tumours were responsible for $63.6 \%$ [35.4-84.8] of all tumour perforation cases. Perforation was seen in $10.1 \%$ [4.9 - 19.2] of pT4 cases (Table 5).

Table 5. Frequency of colorectal carcinoma perforation by the $\mathrm{pT}$ characteristics

\begin{tabular}{|l|c|c|c|}
\hline $\begin{array}{l}\text { Para- } \\
\text { meter }\end{array}$ & $\begin{array}{c}\text { Number of } \\
\text { perforated } \\
\text { cases }\end{array}$ & $\begin{array}{c}\text { Total case } \\
\text { count } \\
\text { by pT }\end{array}$ & $\begin{array}{c}\text { Frequency of } \\
\text { perforation, \% } \\
\text { [95\% confidence } \\
\text { interval] }\end{array}$ \\
\hline pT1 & 0 & 7 & $0.0[0.0-40.4]$ \\
\hline pT2 & 2 & 20 & $10.0[2.8-30.1]$ \\
\hline pT3 & 2 & 77 & $2.6[0.7-8.9]$ \\
\hline pT4 & 7 & 69 & $10.1[5.0-19.5]$ \\
\hline
\end{tabular}

Synchronous second colorectal carcinoma was identified in 17 cases or $9.8 \%$ [6.2 - 15.2]. The other cancer was mostly associated with pT4 cases, namely, it was revealed in 9 patients constituting 13.0\% [7.0 - 22.9] of all pT4 cases. Among the patients with synchronous other carcinoma, lymph node metastases $(\mathrm{pNl}$ and pN2) were detected in 9 cases, accounting for $52.9 \%$ [31.0 - 73.8] of the patients affected by synchronous second carcinoma and $10.5 \%$ [5.6 - 18.7] of the total number of cases displaying lymph node metastases.

Residual adenomas in our study were detected in $19.1 \%$ [13.9 - 25.6] of cases, mostly in patients with pT3 and pT4 characteristics of local spread (Table 6).

Table 6. Frequency of residual adenoma by $\mathrm{pT}$ in colorectal cancer

\begin{tabular}{|l|c|c|}
\hline $\begin{array}{c}\text { Para- } \\
\text { meter }\end{array}$ & $\begin{array}{c}\text { Number of cases } \\
\text { exhibiting residual } \\
\text { adenoma }\end{array}$ & $\begin{array}{c}\text { Frequency, \% [95\% } \\
\text { confidence interval] }\end{array}$ \\
\hline pT1 & 3 & $42.9[15.8-75.0]$ \\
\hline pT2 & 6 & $30.0[14.5-51.9]$ \\
\hline pT3 & 15 & $19.5[12.2-29.7]$ \\
\hline pT4 & 9 & $13.0[7.0-23.0]$ \\
\hline
\end{tabular}

In the whole study group, tumour invasion in lymphatic vessels was found in 82 cases or $47.4 \%$ [40.1 - 54.8] of patients. There was no lymphatic invasion in pTl tumours: $0 \%$ [0 -35.4]. Regarding pT2 carcinomas, such invasion was found in 3 cases, corresponding to $15.0 \%$ [5.2 - 36.0] of pT2 cases. Evaluating the lymphatic invasion in pT3 and pT4 tumors, it was present in $35.1 \%$ [25.3 - 46.2] of pT3 and 75.4\% [64.0 - 84.0] of pT4 cases. The statistical significance of the observed difference was confirmed by $\mathrm{p}<0.001$. Invasion into veins was observed in 29.0\% [19.6-40.6] of pT4 cases, but intraneural growth - in $47.8 \%$ [36.5 - 59.4] of pT4 carcinomas. Both findings were significantly more frequent than in pT3, p $=0.002$. Perineural cancer invasion in pT3 and pT4 tumours were found in $29.9 \%$ [20.8 - 40.9] and 69.6\% [57.9 - 79.2], respectively (Table 7). The statistical significance of the observed difference was again confirmed by $\mathrm{p}<0.001$.

Table 7. Manifestations of invasive growth in pT3 and pT4 colorectal carcinoma

\begin{tabular}{|l|c|c|c|c|}
\hline \multirow{2}{*}{$\begin{array}{c}\text { Para- } \\
\text { meter }\end{array}$} & \multicolumn{3}{|c|}{ Frequency, \% [95\% confidence interval] } \\
\cline { 2 - 5 } & $\begin{array}{c}\text { Lymphatic } \\
\text { invasion }\end{array}$ & $\begin{array}{c}\text { Venous } \\
\text { invasion }\end{array}$ & $\begin{array}{c}\text { Perineural } \\
\text { invasion }\end{array}$ & $\begin{array}{c}\text { Intraneural } \\
\text { invasion }\end{array}$ \\
\hline pT3 & $35.1[25.3-$ & $9.1[4.5-$ & $29.9[20.8-$ & $14.3[8.2-$ \\
& $46.2]$ & $17.6]$ & $40.9]$ & $23.8]$ \\
\hline pT4 & $75.4[64.0-$ & $29.0[19.6$ & $69.6[57.9-$ & $47.8[36.5-$ \\
& $84.0]$ & $-40.6]$ & $79.2]$ & $59.4]$ \\
\hline
\end{tabular}

\section{DISCUSSION}

Colorectal cancer as the one of the leading cause of death in the world spears neither women nor men. In the present stydy, occurrence in both genders was observed as well. In our study, only $4.6 \%$ of patients were younger than 50 years. Hypothetically, younger patients can more frequently present with unresectable tumour [Berut et al., 2013], and such cases undergoing palliative treatment only would be excluded from the present study focusing on major surgical resections. By literature data, younger patients have higher frequency of American Joint Committee on Cancer stage III carcinomas exhibiting vascular and perineural invasion [Ghazi et al., 2012]. In Latvia, many patients are diagnosed after the age of 50 years, therefore screening for colorectal cancer, beginning from the age of 50 years, would have high diagnostic yield.

In our study, significant fraction of mucinous colorectal carcinoma was localised in left side of large bowel, while in other studies mucinous carcinoma has been localised mostly in right side of colon [Nawa et al., 2008]. Considering the known association between mucinous differentiation and molecular types in colorectal cancer [Umar etal., 2004], different distribution of these types can be suspected in Latvia. Such differences hypothetically can be attributable both to risk factor distribution and genetic predisposition. Obviously, larger studies are necessary to solve this issue. This study did not focus to study the genetic predisposition. Only 40 cases in our study were right-sided tumours, which in literature are associated with positive family history [Ponz de Leon et al., 1990]. The low rate of young patients also 
is not suggestive of frequent hereditary predisposition. However, this finding is by no means exclusive as hereditary cancers can also develop in aged patients [Vanags et al., 2010].The pT4 tumours have a tendency to more frequent perforation. It could be associated with tumour spread through all layers of the bowel wall. However, tumour necrosis and inflammation should be analyzed in association of perforation in further studies, because, as our study showed, perforation was not limited by pT4, where tumour has spread further than lamina muscularis propria and has reached bowel surface. Surgically induced perforation at the tumour site can also develop. To discriminate such event from the true tumour perforation, clarification from surgeons can be helpful [Fleming et al., 2012].

Patients affected by pT4 cancer in our study in 13\% of all cases had synchronous second carcinoma. There are published data that patients with synchronous colorectal carcinomas have also higher incidence of benign polyps [Abe et al., 2006].

By recent estimates, perineural invasion can have similar prognostic role as lymphovascular invasion [Compton et al., 2012; Gagliardi et al., 2013]. Our study showed that $69.6 \%$ pT4 tumours had perineural and $75.4 \%$ lymphatic invasion, while invasion in vessels were found only in $29.0 \%$ of pT4 cases. Notably, the perineural, lymphatic and vascular invasion was statistically significantly more frequent in pT4 carcinomas suggesting inherent higher invasive capacity in these advanced tumours.

The mostly accepted guidelines for colorectal carcinoma investigation suggest that at least 12 lymph nodes must be retrieved. However, variations exist between different countries [Compton et al., 2000; Kuijpers et al., 2013]. In our study, at least 12 lymph nodes were identified in $46.2 \%$ of patients, while in $26.0 \%$ cases the number of retrieved lymph nodes was 8 to 11 and in $27.8 \%$ - less than 8 lymph nodes were identified. This is in accordance with Zhang et al., recently reporting that only $27.9 \%$ of colorectal patients had at least 12 examined lymph nodes [Zhang et al., 2013]. In addition, many authors have noted that the target number of 12 retrieved lymph nodes is not always possible to reach even in USA and European clinics [Li Destri et al., 2014]. In northwest of England, at least 12 lymph nodes have been identified in less than $50 \%$ of resected colorectal cancer materials [Mitchell et al., 2009]. Similarly, Johnson et al. reported that 12 lymph nodes have been retrieved only in $55.3 \%$ of colorectal surgery materials including any removed lymph nodes [Johnson et al., 2010]. The Dutch Surgical Colorectal Audit recognised that at least 10 lymph nodes have been examined in $73 \%$ of colon cancers and $58 \%$ of rectal cancers [Kuijpers et al., 2013]. The median value of identified lymph nodes in our study was 11 . In United States, the median number of retrieved lymph nodes has increased from 12 in the year 2004 to 17 in 2010 [Budde et al., 2014]. Thus, our study has identified a clear potential for improvement. However, it must be also emphasised that in USA the growing number of retrieved lymph nodes has not been accompanied by higher frequency of stage III disease [Budde et al., 2014].
Treatment can significantly influence the lymph node yield, especially in rectal tumours [Morcos et al., 2010; Marks et al., 2010]. However, this confounder was rarely observed in the present study. In contrast, the lymph node yield is significantly influenced by the location of tumour. The highest lymph node yield is reported in right-sided cases, exceeding the mean number of identified lymph nodes in left-sided and rectal cancers [Ahmadi et al., 2014]. Our group is characterised by the predominance of left-sided cancers. In addition, most of patients were elderly. Aging can result in diminished activity of immune system [Stocchi et al., 2011], morphologically paralleling lymph node involution [Shia et al., 2012]. It has been suggested that the mean lymph node yield decreases by 1 for every 7 years advancement of age [Ahmadi et al., 2014] or by $9 \%$ for every 10 years of age [Chou et al., 2010]. To improve the assessment of tumour dissemination via lymphatic route, is has been suggested to evaluate the lymph node ratio, i.e. the ratio between the number of metastatic and examined lymph nodes [Costi et al., 2014] or the log odds of positive lymph nodes [Arslan et al., 2014]. Stage migration phenomenon has been recognized in colon carcinoma implying that lower tumour stages have been identified, e.g., in patients undergoing treatment in non-teaching hospitals or in hospitals where lymph nodes were retrieved by less experienced clinicians. However, even under these circumstances there were no interinstitutional differences in recurrence according to tumour stage [Ueno et al., 2014]. Thus, our data display the actual problems and challenges in colorectal cancer surgery.

\section{CONCLUSIONS}

1. Colorectal cancer occurs with equal frequency in both sexes, often after the age of 60. Colorectal cancer screening would have high efficiency if started at the age of 50 years.

2. Among radically operated colorectal cancers, adenocarcinoma is the predominant histological type. Rectum is the most frequently affected anatomic localisation. Frequent localisation of mucinous colorectal carcinoma in left side of the intestine was found. However, wider studies are desirable.

3. The pT4 tumours have a tendency to increased frequency of perforation. It could be associated with but not limited by transmural tumour spread.

4. The pT4 colorectal cancer is characterized by invasion of lymphatic vessels, perineural and intraneural invasion. Perineural and lymphatic invasion in pT4 tumours was statistically significantly more frequent than in less advanced cancers and can be pathogenetically associated with wide local tumour spread.

\section{Conflict of interest: None}




\section{REFERENCES}

1. Abe S, Terai T, Sakamoto N, Beppu K, Nagahara A, Kobayashi O, Ohkusa T, Ogihara T, Hirai S, Kamano T, Miwa H, Sato N. Clinicopathological features of nonpolypoid colorectal tumors as viewed from the patients' background // J Gastroenterol, 2006; 41:325 - 331

2. Ahmadi O, Stringer MD, Black MA, McCall JL. Influence of age and site of disease on lymph node yield in colorectal cancer // N Z Med J, 2014; 127: $31-40$

3. Altman DG, Machin D, Bryant TN, Gardner RJ. Statistics with confidence. 2nd ed. Bristol: BMJ Books; 2000

4. Arslan NC, Sokmen S, Canda AE, Terzi C, Sarioglu $\mathrm{S}$. The prognostic impact of log odds of positive lymph nodes in colon cancer // Colorectal Dis, 2014; doi: $10.1111 /$ codi.12702

5. Berut M, Mik M, Kedzia-Berut R, Kujawski R, Trzcinski R, Dziki L, Dziki A. Colorectal cancer in young and elderly patients // Polski Przeglad Chirurgiczny, 2013; 8:446-451

6. Bhangu A, Brown G, Nicholls RJ, Wong J, Darzi A, Tekkis P. Survival outcome of local excision versus radical resection of colon or rectal carcinoma: a Surveillance, Epidemiology, and End Results (SEER) population-based study // Ann Surg, 2013, 258: 563 - 571

7. Budde $\mathrm{CN}$, Tsikitis VL, Deveney KE, Diggs BS, Lu $\mathrm{KC}$, Herzig DO. Increasing the number of lymph nodes examined after colectomy does not improve colon cancer staging // J Am Coll Surg, 2014; 218:1004- 1011

8. Compton CC, Byrd DR, Garcia-Aguilar J, Kurtzman $\mathrm{SH}$, Olawaiye A, Washington MK. AJCC Cancer Staging Atlas, 2nd ed. NewYork, Springer, 2012; $185-202$

9. Compton CC, Fielding LP, Burgart LJ, Conley B, Cooper HS, Hamilton SR, Hammond ME, Henson DE, Hutter RV, Nagle RB, Nielsen ML, Sargent DJ, Taylor CR, Welton M, Wilett C. Prognostic factors in colorectal cancer. College of American Pathologists consensus statement 1999 // Arch Pathol Lab Med, 2000; 124:979 - 994

10. Costi R, Beggi F, Reggiani V, Ricco M, Crafa P, Bersanelli M, Tartamella F, Violi V, Roncoroni L, Sarli L. Lymph node ratio improves TNM and Astler-Coller's assessment of colorectal cancer prognosis: an analysis of 761 node positive cases // J Gastrointest Surg, 2014; E-pub ahead of print, accessed 11.08.2014.

11. Cunliffe WJ, Hasleton PS, Tweedle DE, Schofield PF. Incidence of synchronous and metachronous colorectal carcinoma // Br J Surg, 1984; 71:941 943

12. Edge SB, Byrd DR, Compton CC, Fritz AG, Greene FL, Trotti A III. AJCC cancer staging manual, 7th ed. New York, Springer, 2010; 173 - 206

13. Fleming M, Ravula S, Tatishchev SF, Wang HL. Colorectal carcinoma: Pathologic aspects // J Gastrointest Oncol, 2012; 3: 153-173
14. Gagliardi G, Newton TR, Bailey HR. Local excision of rectal cancer followed by radical surgery because of poor prognostic features does not compromise the long term oncologic outcome // Colorectal Dis, 2013; 15:659-664

15. Ghazi S, Lindforss U, Lindberg G, Berg E, Lindblom A, Papadogiannakis N; Low-Risk Colorectal Cancer Study Group. Analysis of colorectal cancer morphology in relation to sex, age, location, and family history // J Gastroenterol, 2012; 47:619 634

16. Hamilton SR, Aaltonen LA. World Health Organisation classification of tumours, pathology and genetics of tumors of the digestive system, 4th ed. Lyon, IARC Press, 2010; $103-145$

17. Johnson A, Rees JR, Schwenn M, Riddle B, Verrill C, Celaya MO, Nicolaides DA, Cherala S, Feinberg M, Gray A, Rutstein L, Katz MS, Nunnink JC. Oncology care in rural northern new England // J Oncol Pract, 2010; 6:81 - 89

18. Kuijpers CC, van Slooten HJ, Schreurs WH, Moorman GR, Abtahi MA, Slappendel A, Cliteur $\mathrm{V}$, van Diest PJ, Jiwa NM. Better retrieval of lymph nodes in colorectal resection specimens by pathologists' assistants // J Clin Pathol, 2013; 66: $18-23$

19. Li Destri G, Di Carlo I, Scilletta R, Sciletta B, Puleo S. Colorectal cancer and lymph nodes: the obsession with the number 12 // World J Gastroenterol, 2014; 20:1951 - 1960

20. Marks JH, Valsdottir EB, Rather AA, Nweze IC, Newman DA, Chernick MR. Fewer than 12 lymph nodes can be expected in a surgical specimen after high-dose chemoradiation therapy for rectal cancer // Dis Colon Rectum, 2010; 53:1023 - 1029

21. Marzouk O, Schofield J. Review of histopathological and molecular prognostic features in colorectal cancer // Cancers (Basel), 201 1; 3:2767 - 2810

22. Mitchell PJ, Ravi S, Grifftiths B, Reid F, Speake D, Midgley C, Mapstone N. Multicentre review of lymph node harvest in colorectal cancer: are we understaging colorectal cancer patients? // Int J Colorectal Dis, 2009; 24:915 - 921

23. Morcos B, Baker B, Al Masri M, Haddad H, Hashem S. Lymph node yield in rectal cancer surgery: effect of preoperative chemoradiotherapy // Eur J Surg Oncol, 2010; 36:345 - 349

24. Nawa T, Kato J, Kawamoto H, Okada H, Yamamoto $\mathrm{H}$, Kohno H, Endo H, Shiratori Y. Differences in right- and left-sided colon cancer in patient characteristics, cancer morphology and histology // J Gastroenterol Hepatol, 2008; 23:418 - 423

25. Ponz de Leon M, Sacchetti C, Sassatelli R, Zanghieri G, Roncucci L, Scalmati A. Evidence for the existence of different types of large bowel tumor: suggestions from the clinical data of a populationbased registry // J Surg Oncol, 1990; 44:35 - 43

26. Shia J, Wang H, Nash GM, Klimstra DS. Lymph node staging in colorectal cancer: revisiting the benchmark of at least 12 lymph nodes in R0 resection // J Am Coll Surg, 2012; 214:348 - 355 
27. Stocchi L, Fazio VW, Lavery I, Hammel J. Individual surgeon, pathologist, and other factors affecting lymph node harvest in stage II colon carcinoma. Is a minimum of 12 examined lymph nodes sufficient? // Ann Surg Oncol, 2011; 18:405 - 412

28. Swamy R. Histopathological reporting in pT4 tumor stage in colorectal carcinomas: dotting the ' $i$ 's and crossing the 't's // J Clin Pathol, 2010; 63:1 10 - 115

29. Takeuchi H, Toda T, Nagasaki S, Kawano T, Minamisono Y, Maehara Y, Sugimachi K. Synchronous multiple colorectal adenocarcinomas // J Surg Oncol, 1997; 64:304-307

30. Ueno H, Hase K, Hashiguchi Y, Shinto E, Shimazaki H, Yamamoto J, Nakamura T, Sugihara K. Potential causes of stage migration and their prognostic implications in colon cancer: a nationwide survey of specialist institutions in Japan // Jpn J Clin Oncol, 2014; 44:547 - 555

31. Umar A, Boland R, Terdiman JP, Syngal S, de la Chapelle A, Ruschoff J, Fishell R, Lindor NM, Burgart LJ, Hamelin R, Hamilton SR, Hiatt RA, Jass J, Lindblom A, Lynch HT, Peltomaki P, Ramsey SD, Rodriguez-Bigas MA, Vasen HFA, Hawk ET, Barrett JC, Freedman AN, Srivastava S. Revised Bethesda guidelines for hereditary nonpolyposis colorectal cancer (Lynch syndrome) and microsatellite instability // J Natl Cancer Inst, 2004; 96:261 - 268
32. Vanags A, Strumfa I, Gardovskis A, Borosenko V, Abolins A, Teibe U, Trofimovics E, Miklasevics E, Gardovskis J. Population screening for hereditary and familial cancer syndromes in Valka district of Latvia // Hered Cancer Clin Pract, 2010; 8(1):8, doi: 10.1186/1897-4287-8-8

33. Zhang B, Lv M, Chen T, Wei Q, Wang G, Tian J, Chen $\mathrm{B}$. The association between lymph node resection and postoperative survival in patients with colorectal cancer // Hepatogastroenterology, 2013; 60:1922 - 1926

34. Walsh SV, Carey FA. Malignant epithelial neoplasms of the large bowel // In: Shepherd NA, Warren BF, Williams GT, Greenson JK, Lauwers GY, Novelli MR. Morson and Dawson's gastrointestinal pathology, 5th ed. Oxford, Blackwell Publishing, 2013; 685 732

\section{Address:}

Ilze Strumfa

Department of Pathology, Riga Stradins University

Dzirciema Street 16, LV-1007, Riga, Latvia

E-mail: Ilze.Strumfa@rsu.lv 